\title{
A Life with Boundless Energy: a Tribute to Former AACE President, John L. Currie (1942-2015)
}

\author{
Joseph F. O'Donnell ${ }^{1}$
}

Published online: 7 July 2015

(C) American Association for Cancer Education 2015

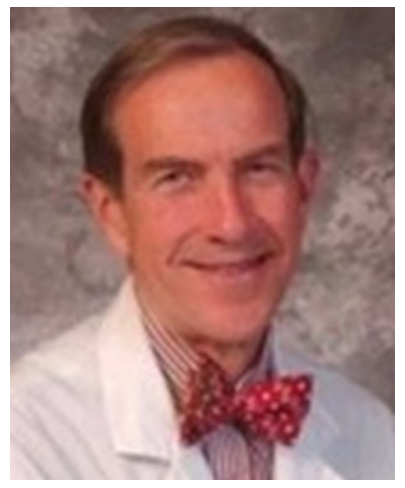

The Reader's Digest magazine used to have a regular piece in each issue about "the most unforgettable character I've ever met". Dr. John A. Currie is one of the most unforgettable characters I have ever met. Tragically, the world lost his talents and energy at the age of 73 on April 22, 2015. He died surrounded by his five children and their families in his beloved Asheville, North Carolina. He always was a proud "tarheel."

He was a past leader for our AACE, a visionary doctor, and a person with infectious energy that he spread to those around him. He was one of a small group of visionary leaders who turned the course of the great ship of AACE from a place of instability to a place with a solid foundation to build upon. John took over the finance and treasurer's role and with several others at a time of crisis, his self-described "frugality" helped save the organization and helped establish a resource

Joseph F. O'Donnell

Joseph.F.ODonnell@Dartmouth.edu

1 Hanover, NH, USA

base on which to grow. John assumed the presidency in 1995 and set in motion some of the strategies and procedures that exist today. I remember well his conversation with me about "getting more good papers" for this journal. John established the R. Davilene Carter Presidential Paper awards that had as a requirement that a completed, reviewed manuscript about something presented at this annual meeting was required for consideration, and through this stroke of genius, the floodgates opened for great manuscripts.

John was unique and unforgettable. I want to tell four stories about him.

1) As president-elect, he was chairman of the program committee for the annual meeting at his institution, Johns Hopkins, in 1994. A record number of posters had been submitted and accepted, but somehow, the poster boards to display them did not arrive. No problem. John bought the materials and built the display boards in his basement on the night before the conference. In spite of being up all night, he beamed with pride at his creation!

2) Later in his career, he came up to my home institution at Dartmouth to assume the chairmanship of the ObstetricsGynecology Department. He bought a beautiful Frank Lloyd Wright house in Hanover, and several days later, I was passing in on my way to work, and John had it being jacked up on stilts. He was going to build a first floor under the existing structure. Only John could improve on a Frank Lloyd Wright design and now it is one of the nicest houses in Hanover!

3) Another story can be framed around meeting John everywhere in town it seemed and seeing him always balancing a million balls in the air. Quite early one morning, my wife and I were out walking when we heard this jovial "hi there" from behind. It was John pedaling the oldest bike I think I had ever seen, with a whistle around his 
neck and a bag of basketballs strapped to his back. John said to my wife..."you've got to get Joe out biking on days like this" as he zoomed by, not to be late for back-toback basketball practices for his kids. He was the coach, and he had a great knack for teaching the kids about sports and sportsmanship. John was a whirling dervish, always off to many places, spreading his joy and humor all over. John was a great athlete. He loved sports and teaching his kids about sports. But, early a.m., oldest bike, a whistle in his mouth, basketballs on his back, scurrying off not to be late to teach his kids and others, and always with a smile on his face is how I best remember John.

4) John's other great love was music (and this man had so many loves.....his family was first, his calling to gynecologic oncology, his creative building skills, his athleticism were those I experienced with him). John was a very talented musician himself, but he inspired colleagues to join him. He and a group of other staff at Dartmouth formed a band and their music spread joy. John had this idea of having a "music camp" weekend for patients and their families with cancer. He worked with several musically inclined medical students, and they put on a wonderful music-filled weekend that people still talk about up here.

John was a special guy. Those that met him do not forget his infectious energy and smile.

He had so many interests and passions, and to his credit and a lesson for the rest of us, he acted on them. He was always fascinated by the law and in his "spare" time at Dartmouth, he enrolled at the neighboring Vermont Law School and got his law degree. What a guy!!!

The call of his native south beckoned him back to his roots, and I lost touch with him. His last medical creation was the gynecologic oncology program at the John B. Amos Cancer Center in Columbus, Georgia.

He was a most unforgettable character. He helped stabilize the AACE and, like Johnny Appleseed, he spread quality in gynecologic oncology everywhere he went from North Carolina, to Johns Hopkins, to Dartmouth, to Hartford, Connecticut, to Vanderbilt, and finally to Columbus, Georgia.

The world will miss this unforgettable character with so many talents. I will bet he is entertaining those in heaven right now and keeping them active, singing, and laughing. 